TURIZAM

Volume 22, Issue 1

1-9 (2018)

ORIGINAL

SCIENTIFIC PAPER

\title{
Interactive Environmental Garden and its Role in Rural Tourism Development, Slovakia
}

\author{
Mária BihuňováA \\ Received: March 2018 | Accepted: April 2018 \\ DOI: $10.5937 / 22-17510$
}

\begin{abstract}
Rural tourism is still not effectively developed in Slovakia. There are documents and activities of nongovernmental organisations that promote the countryside, culture, agricultural activities, the uniqueness of the landscape but they are not systemic and without strong legal background. In the southern part of Slovakia - The Danube Lowland - is rich with natural, cultural and architectural sites, thermal springs, possibilities for water tourism in the river Small Danube, and places for agro tourism, etc. The development of the region supports the character of the terrain and appropriate conditions for modest cycling. The Environmental Education Centre (EEC) Dropie - an educational organization of the Slovak Environmental Agency in Zemianska Olča is a unique site providing recreational and educational activities, with the possibility to spend overnights in the centre. It is the biggest environmental centre in Slovakia and it is aimed (except the issues regarding natural protection) at the education and promotion of the bustard (Otis tarda) one of the heaviest flying birds in the world. This bird has a territory of the natural occurrence along the border between Slovakia, Hungary and Austria. The EEC Dropie is situated in the agricultural land, characterized by large-scale block fields, surrounded by Special Protection Area of the Island Meadows and the NATURA 2000 site. The students of the Slovak University of Agriculture in Nitra, Faculty of Horticulture and Landscape Engineering were invited to create landscape architectural designs for the centre focusing on easier and demonstrative outdoor education for the public and especially children.
\end{abstract}

Keywords: environmental education, design of educational gardens, landscape architecture, rural tourism, Slovakia

\section{Introduction}

Rural tourism represents recreational activities related to rural areas with the possibility for accommodations in family houses, in rural houses or in specialized agricultural centers and farms. Rural tourism is supported by engaging visitors in activities related to production and processing of plant and animal products or active help with agricultural work (Gúčik, 200o).

A Slovak University of Agriculture in Nitra, Faculty of Horticulture and Landscape Engineering, Department of Garden and Landscape Architecture, Tulipánová 7. 94976 Nitra, Slovakia; bihunova.maria@gmail.com 
The development of rural tourism promotes not only the attractiveness of the countryside, traditions, crafts, handmade products, but gastronomy, nature and lifestyle. The main thing is the offer of quality services, especially leisure and recreational activities (active, passive, educational, interactive, adventure). According to Flekalova (2015), the rural landscape represents a recreational landscape of the future.

The OECD Member States have set a limit of 150 inhabitants per $\mathrm{km}^{2}$ as a criterion for the countryside. According to this criterion, $78.4 \%$ of the population in Slovakia lives in countryside. Predominantly rural regions live $48 \%$ of the population, $40 \%$ of the population in transition regions and only $12 \%$ are in urbanized regions. According to the proportion of regional income in EU countries, agriculture and forestry currently does not create the keystone of the rural economy. The same situation is in Slovakia, where this income represents $5 \%$ in agriculture and $1.3 \%$ in forestry (Internet 1 ).

The role of municipalities, cities and regions lies in their active involvement in rural tourism and agro-tourism, thus contributing to improving the traffic connections, increasing the employment of the locals, raising the living standards of the inhabitants, promotion of the local and regional uniqueness or differences (Kerekeš, 2015).

Environmental awareness of the public leads to the sustainable development of recreation considering nature and landscape protection (Bell et al., 2009).

Recreation and regeneration of psychical and physical health could have different forms: having fun, relaxation, education - observing, relaxing in the natural environment, physical activity (Pichlerová, Benčat', 2009).

The Environmental Education Centre (EEC) DROPIE of the Slovak Environment Agency in Zemianska Olča offers all types of recreational forms. Its main aim is environmental education for all age categories, schools, visitors, public.

Environmental education targets the development of children's personality by acquiring the ability to understand, analyze and evaluate the relationships between human and their environment, while understanding the need for responsible environmental behaviour. It is important to share knowledge and skills through simple activities, which helps users understand the ecosystems complexes and consequences of human behaviour (Internet 2).

In the current state educational program in Slovakia, environmental education is understood as a cross section theme, which is included in several subjects from elementary school to high school and universities. In that process, the teachers play an irreplaceable role (Moyseová, 2016). Besides pedagogues, the specialist of state and public organizations, employees of nongovernmental organizations in the field of nature conservation and landscape protection have a great challenge.

According to the Environmental Minimum, which was approved by the Ministry of Education of the Slovak Republic in 1996, the teacher focuses on three basic aspects: the level of knowledge, the development of skills and formation of the appropriate attitudes (Moyzeova, 2016).

Schoolyards, gardens playgrounds, environmental centres are outdoor places, where children can interact, play and learn. To create that kind of spaces, three design steps are used:

1. Research - side inventory, analysis of the current situation, demand of the investor or administrator, future plans;

2. Landscape architectural design, which could be in cooperation with a psychologist, or environmentalist;

3. Construction documentation, cost estimating and implementation (Tai et al., 2006). 
In relation to recreational spaces, this means that we should know for whom we design, and take into consideration the specific needs accordingly. When designing open spaces, we should always keep in mind that it is never a standalone unit. There is always the urban or peri-urban context that should be taken into consideration. Even in the case of a green field or brownfield development, the concept should be guided by the spirit of the place. This way the new design will not only blend in with its surrounding, but may also strengthen the local identity. In the case of recreation, this means that existing features that may provide or enrich the recreational resource base should be appreciated and integrated into the design proposal (Supuka, Vreštiak, 1984; Probstl et al. (Ed.), 2010; Štepánková, Bihuňová, Kabai, 2012).

The design of a trail, which encompasses not only technical but also aesthetic and interpretive aspects, is influenced by many different factors: Ecological conditions, Functional requirements, Aesthetic factors (Bell, 2001).

Choosing the method of communication is one of the most decisive factors in producing a successful interpretive trail. Communication methods for interpretive trails can be divided into descriptive (transmit information via text, graphics, tables, diagrams and pictures), interactive (methods stimulating an active way of learning and leading the visitors to find out about things themselves), sensory ways of communication (incorporate the visitors'senses: seeing, hearing, smelling, tasting and touching). Experience trails combine all three methods (Gebhard et al., 2007). Kotradyová et al. (2015) says about the learning through experiences as effective tool how transform information into the knowledge.

\section{Methodology}

The methods, which were used are the following (same as are mentioned in the methodology Tai et al., 2006): 1.terrain analyses, analysis of the greenery, SWOT analyse, 2. Analyse of the environmental programs, which SEV offers, analyse of the visitors, 3. Analysis of future plans of EEC Dropie. Terrain analyses represent definition of the location, survey of the surrounding, actual land use, studying documents regarding the nature and landscape protection, analysis of the current traffic connection and connections to the services in nearby villages. Greenery was evaluated according to the tree species, health condition and placement in the area. EEC Dropie offers several environmental programs for individuals, school groups and families. Educational programs are thematic named: Fly, fly everything flies (bird watching); Walking through Drop of the Kingdom; Tree, meet a friend; Secrets of the willow trees; Story of the water and its forms; Lowland landscape and many more.

Outdoor and indoor analyses were done in March and April 2017. In April and May 2017 the design process was developed by the students of landscape architecture study program of Faculty of Horticulture and Landscape Engineering, Slovak University of Agriculture in Nitra. Students were supervised by professional. In June 2017 the landscape architectural proposals were presented to the representatives of the EEC Dropie and SEA. The head of the SEA has applied for financial support for the project and the reconstruction of the EEC Dropie.

\section{Study area}

The Environmental Education Centre (EEC) Dropie of the Slovak Environment Agency (SEA) in Zemianska Olča is an organizational unit of the Ministry of Environment of the Slovak Republic. Location of the EEC Dropie is at Figure 1. The EEC is surrounded by the Special Pro- 

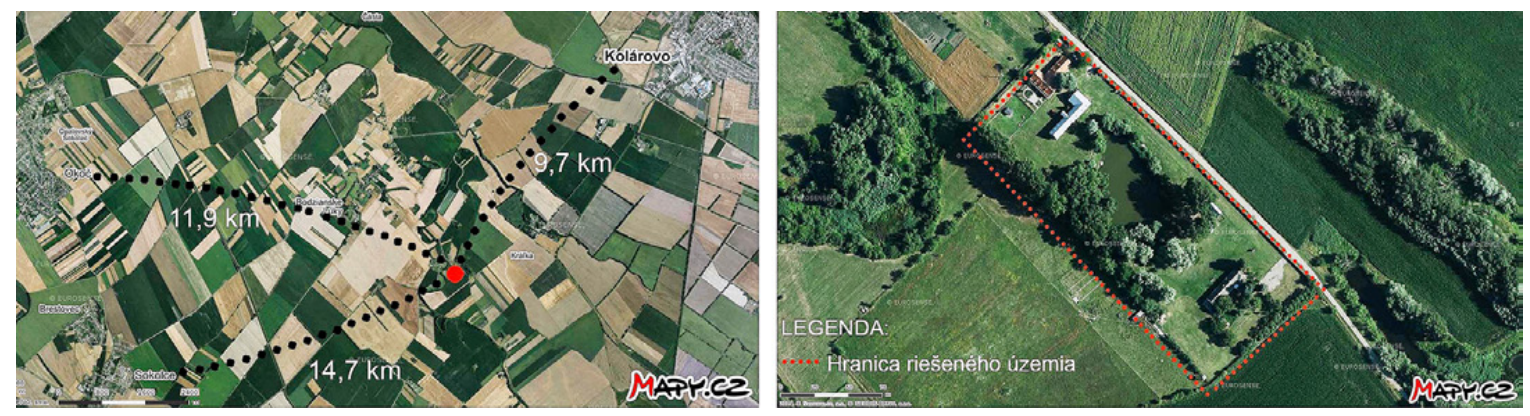

Figure 1. Location of the Environmental Educational Centre Dropie Source: Kubičárová et al., 2017

tection Area Ostrovné lúky, and the NATURA 2000 site. The EEC offers educational activities for the schools and visitors.

There is accommodation for 40 persons, outdoor places for camping, indoor and outdoor rooms for creative workshops and activities, interactive educational classroom, an herb garden and a small farm (Figure 2). There is also a fragment of luscious forest and pond in the EEC Dropie area.

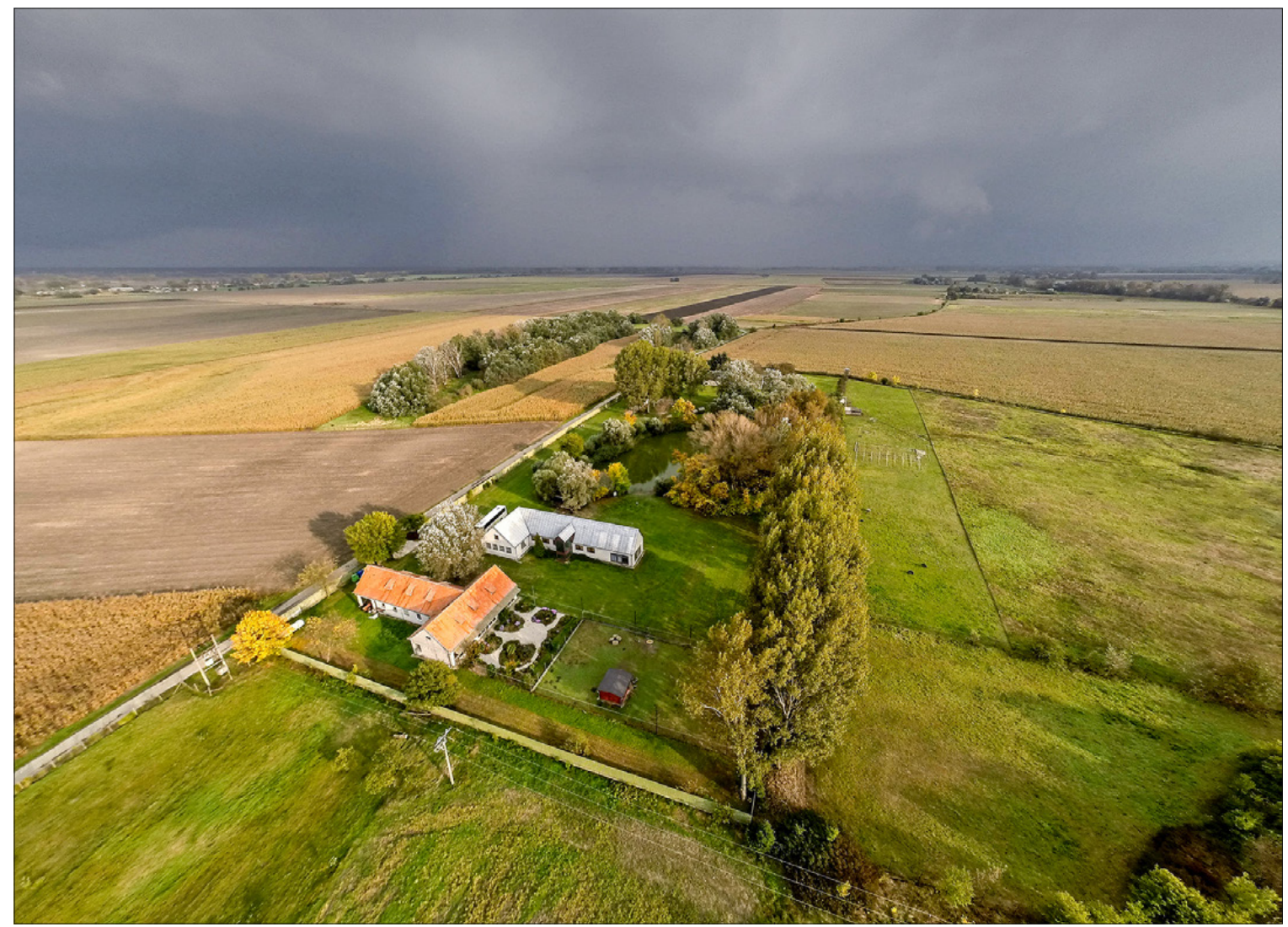

Figure 2. Areal view of the EEC Dropie Source: www.dropie.sazp.sk 
Podunajská lowland, where EEC Dropie is situated, is not only the warmest part of Slovakia, but it is also one of the driest regions (the area is protected from the western winds by the Alps and Small Carpathians), the average annual precipitation is $550-600 \mathrm{~mm}$. Most rainfall falls is in May, June and July - $59.3 \mathrm{~mm}$ on average per month.

Biodiversity in the surrounding was significantly influenced by the historical landscape structure of Žitný ostrov. Scattered rural settlements with adjoining farms provide valuable habitats in intensively farmed land (Internet 3).

The basic and fundamental document about nature and landscape protection in the Slovak Republic is the Act No.543/2002 on Nature and Landscape Conservation. Separately from the national system there are "protected bird areas" and "areas of European importance" signed in the framework of the European system of protected areas NATURA 2000 (Moravčík et al., 2007, Tóth et al., 2014).

The Convention on the Wetlands of International importance, especially as Waterfowl Habitat, is also known as the Ramsar Convention. Slovakia became a contract partner to the Ramsar Convention on the $1^{\text {st }}$ January 1993.

\section{Results}

Result of our work is presented as landscape architectural proposal of the environmental center Dropie, with aim to strengthen the local genius loci and potential of the side and create the possibilities for different aspects of outdoor environmental education.

SWOT analysis was one of the several analysis done in EEC Dropie. According to the SWOT analysis we have defined strengths sides and weaknesses, opportunities and threats as follow:

Table 1. SWOT analysis of the EEC Dropie

\begin{tabular}{|l|l|}
\hline STRENGTHS & WEAKNESSES \\
\hline $\begin{array}{l}\text { - location and area, } \\
\text { natural environment, } \\
\text { variability of the site, } \\
\text { enthusiastic employees, } \\
\text { the biggest environmental center in Slovakia, } \\
\text { - demand for outdoor education from the schools }\end{array}$ & $\begin{array}{l}\text { difficult accessibility, } \\
\text { low outdoor educational equipment, } \\
\text { difficult access for disabled children } \\
\text { limited parking }\end{array}$ \\
\hline $\begin{array}{l}\text { OPPORTUNITIES } \\
\text { - } \quad \begin{array}{l}\text { EU grants or grant from the Ministry, } \\
\text { increasing interest from the schools and public, } \\
\text { good references, } \\
\text { advertisement }\end{array}\end{array}$ & $\begin{array}{l}\text { THREATS } \\
\text { inefficient traffic signs which promote EEC Dropie }\end{array}$ \\
\hline
\end{tabular}

Landscape architectural proposal of the EEC Dropie presents allocation of the different activities within the garden (see Figure 3). The main - the representative zone leads to the administrative building, where offices, workshop rooms and the museum dedicated to the bustard (Otis tarda), one of the heaviest flying birds in the world, are located. Between the administrative building and Guest house is the rain garden, where rain water will be collected from the roofs and special plant species will be planted.

Behind the main building is great area with herb and vegetable gardens. Some of the plots are elevated, which enable work with plants and soil for the children on the wheelchairs as well, 


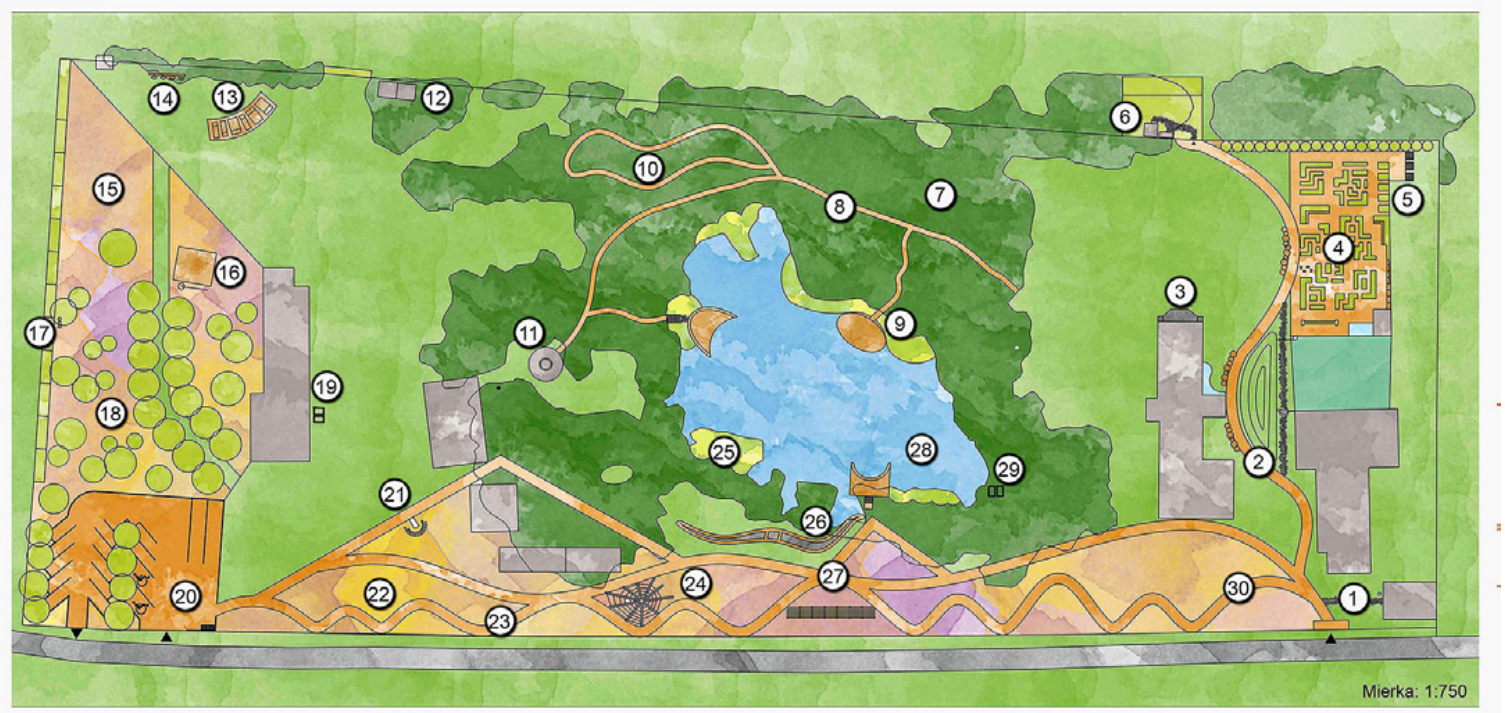

Figure 3. Landscape architectural proposal of the EEC Dropie Source: Kubičárová et al, 2017

\begin{tabular}{|c|c|c|c|c|}
\hline LEGEND: & 6 Poultry house and & 12 Hay barn & 19 Eco toilet & 26 Bare feet path \\
\hline 1Stone path & rabbit house & 13 Rest zone & 20 Parking lot & 27 Deck chairs \\
\hline 2 Rain garden & 7 Willow sculptures & 14 Archery & 21 Sun clock & 28 Pond \\
\hline 3 Collector of the water & 8 Forest path & 15, 22 Flower meadow & 23 Interactive and & 30 Paths is made of \\
\hline 4 Vegetable and herb & 9 Moles & 16 Water well & educational path & extracted grains \\
\hline garden & 10 Monkey way & 17 Bee houses & 24 Spider net for rest & \\
\hline 5 Compost & 11 Fireplace & 18 Orchard & 25,29 Water plants & \\
\hline
\end{tabular}

presented at Figure 4. In the vegetable garden there are climbing plants and grapes. At the corner of the garden is organic waste composting. The poultry house and rabbit house are close to the vegetable garden. There is also big farm yard behind.

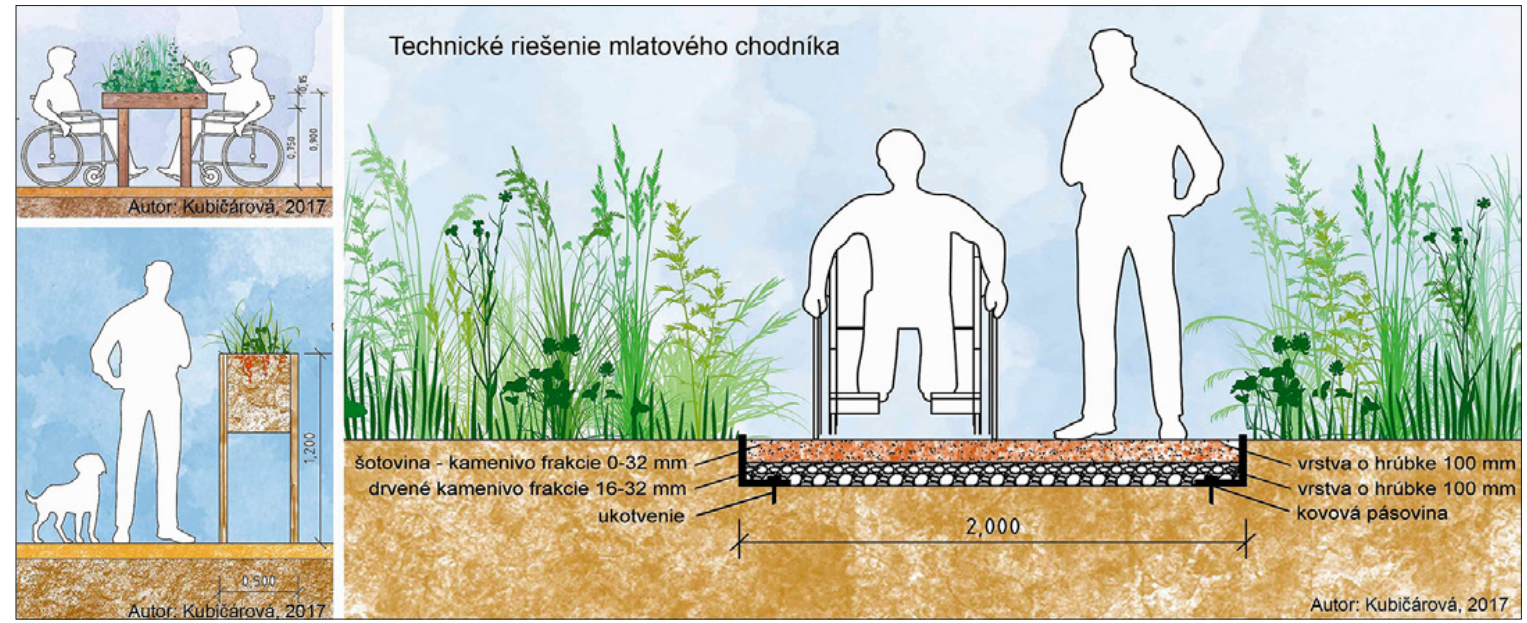

Figure 4. Vegetable garden with elevated tables Source: Kubičárová et al, 2017 
There are fragments of a luscious forest and pond in the central area. The forest is a great place to discover different environments and ecosystems. It is also a place, where children can play, hide and discover. There is a "forest educational path", which leads between the trees. The educational path offers stops along the way to learn something or places for exercise, "fit trail," and also places for rest spots in the nets. Forest willow caches are placed at the entrance.

An outdoor classroom will be built next year, and it will be extended. The big meadows also offer a place for a fireplace.

The pond is accessible by 3 quay piers, which are stops for explaining the water plants, and for watching the fish, birds or insects.

In close connection to the pond, there is huge interactive and exciting path. The shapes of the paths symbolize different regions in Slovakia - from wavy lowlands through highlands and finally sharp mountains. The surface of the paths is made of extracted grains accessible for everyone. The main - middle - path connects the main building and the parking lot at the opposite side. It is the shortest route to get to the canter. The interactive path and recreational paths are connected with this main road. The interactive path contains information boards with puzzles, brain teasers, graphics and diagrams, tasks involving the senses (smell, sound, taste, touch, eyes) - see the Figure 5. There is also sensual path - willable only with bare feet. You could feel soil, sand, stones with different fractions, bark for mulching, hay, cork cylinders, wooden squares. Each of the educational, environmental and experimental stops are situated in the flower meadow. There are also places for rest in shape of a spider net or deck chairs.

The third part of the garden is dedicated to honey bees, a flower meadow and orchard with old species of fruit trees. The highest point in the garden is view tower, which offers the magnificent view to the landscape.

The main purpose of our proposal was to enhance, improve, but especially enrich the Dropie educational area for visitors of different age categories. To also improve the quality of knowledge by learning with playful interactive elements, information boards and to obtain positive skills and experiences.

The landscape architectural proposal should lead to the improvement of the services of the EEC Dropie, which could help to increase the public demand for this place. EEC Dropie lays in the region where other recreational activities are available. For example: an international cycle road along Danube river, plenty of hot springs with spas (the closest is thermal spa in Velký Meder). Unique technical monuments are the water mills on the Small Danube - Tomášikovo, Kolárovo). There is an Observatory in Hurbanovo. The biggest fortress from the 19thcentury is in Komárno. This localities could broaden the recreational and educational experience of the visitors.
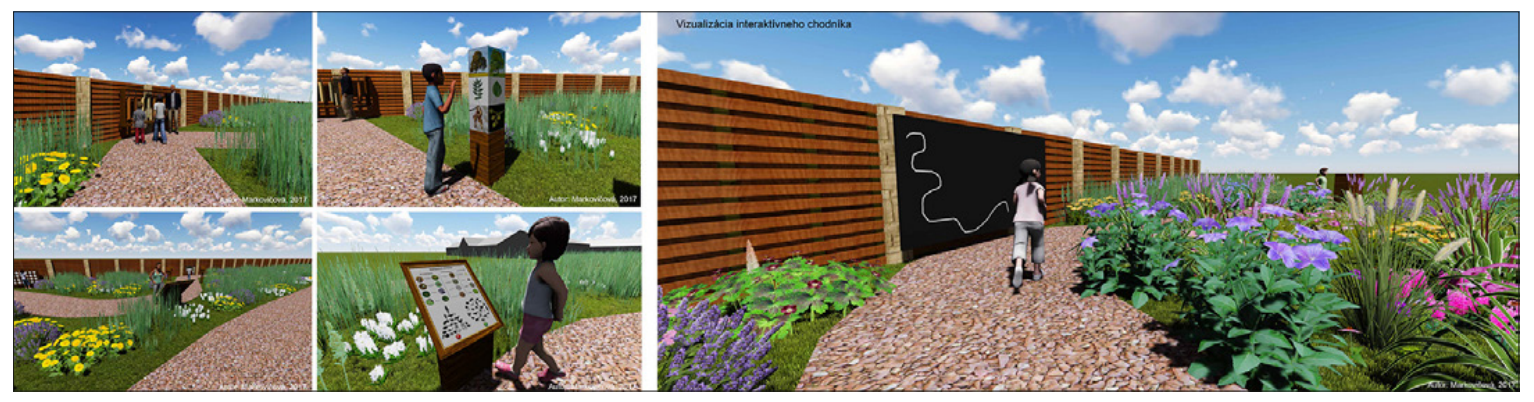

Figure 5. Visualisation of the interactive educational path Source: Kubičárová et al, 2017 


\section{Conclusion}

Environmental education is not new in Slovakia - there is a Program Green School, which joins many children gardens (nursery schools) and primary schools in Slovakia and helps to develop environmental knowledge and skill. Forest pedagogy for all age groups is also and active program. At the Universities the issues regarding the Global Environmental and Ecological Problems (Global Education) are discussed.

Besides the EEC Dropie, there are several environmental centres in Slovakia, but they are not supported by the Ministry, they belong mostly to the non-governmental organizations as: KOSIT and SOSNA in Košice, the Centre for environmental activities in Trenčín, and ŽIVICA in Bratislava, Zvolen and Zaježová. Scientists of the Institute of Landscape Ecology have a Natural environmental laboratory at the Primary school in Suchá and Parnou.

EEC Dropie located in the lowlands, outside of the village offers great possibilities for active or passive environmental education of the visitors. Its employees put great effort to promote the unique locality and to educate children and adults thought experimental and educational programs. As Jakovic, Tubic, Baklan (2016, p. 117) have mentioned - "events are an important motivator of tourism and figured prominently in the development and marketing plans of most destinations". The financial support from the Ministry of Environment of Slovak Republic would help to improve the EEC Dropie and quality of their services.

Danubian lowlands with intensive agricultural production and typical rural architecture reflecting the landscape and materials predestine it for tourism in small agricultural farms or ranches, and the opportunity to engage in agricultural work. The possibility of riding horses multiplies the interest of the stay as well as the attractiveness of the Danube with the possibility of fishing, kayaking, sightseeing through the beautiful landscaped protected areas or visiting the thermal spas (Kerekeš, 2015). Also the conceptual document, which would support the agricultural development is missing in Slovakia, there are only general statements in the official document: Rural Development Programme of the Slovak Republic 2014 - 2020 and Tourism Development Strategy by 2020.

\section{Acknowledgement}

This paper has been elaborated with the support of the grant projects: KEGA oo8SPU-4/2016 "LandArch Studio - Innovation of Teaching Structure, Content and Tools" and KEGA o35SPU4/2016 Interactive Experimental Garden, funded by the Cultural and Educational Grant Agency of The Ministry of Education, Science, Research and Sport of The Slovak Republic

\section{References}

Bell, S. 2001. Design of outdoor recreation. London: Spon Press, 218.

Bell, S., Simpson, M., Probstl,U., Sievanen, T., Tyrvainen, L.(Ed.) 2009. European Forest Recreation and Tourism. A handbook. Great Britain: Taylor and Francis Group, 237.

Flekalová, M. 2015. Udržitelný rozvoj zemědelské krajiny. Brno: MENDELU, 184. (in Czech language) 
Gebhard, K. et al., 2007. The Trail Planning Guide. Principles and Recommendations. Germany: 2007. Ecological Tourism in Europe and UNESCO MaB, 66. Available at: http:// www.oete.de/tourism4nature/results/backdocs/The\%2oTrail\%2oPlanningn\%2oGuide.pdf $(12.6 .2012)$

Gúčik, M. 200o. Základy cestovného ruchu. Banská Bystrica : Ekonomická fakulta UMB, 150. (in Slovak language)

Jakovic, B., Tubic, D., Baklan, R. 2016. Touristic events as generators of visitations increase and tourism sustainability of Nature parks. In: D. Vasiljevic (Ed) Monitoring and Management of Visitors in Recreational and Protected Areas, Abstract book (117 - 119). Novi Sad: Faculty of Sciences.

Kerekeš, J. 2015. Vidiecky cestovný ruch a agroturistika $v$ slovenských obciach a regiónoch. On line : https://www.euroekonom.sk/vidiecky-cestovny-ruch-a-agroturistika-v-slovenskych-obciach-a-regionoch/ (in Slovak language) (12.1.2018)

Kotradyová et.al., 2015. Dizajn s ohl’adom na človeka. Humanizácia mikroprostredia. Bratislava: Slovak Technical University. 302 p. (in Slovak language)

Kubičárová, A., Králová, H., Marek, D., Markovičová, K. 2017. Krajinno architektonické riešenie areálu SEV Dropie. SUA Nitra, 52 (in Slovak language)

Moravčík, M., Novotný, J., Toma, P. 2007. National forest programme of the Slovak Republic. Zvolen: Národné lesnícke centrum, 2007, 63 p. On line: http://www.forestportal.sk/ lesne-hospodarstvo/politika-legislativa/narodna/Pages/narodny-lesnicky-program-Slovenskej-republiky.aspx (in Slovak - English language) (10.12.2017)

Moyzeová, M. 2016. Environmentálna výchova na základných školách. In: Životné prostredie 4/50, 243-247. (Slovak language)

Pichlerová, M, Benčat', T. 2009. Tourism in the landscape. Zvolen: TU vo Zvolene, 116. (in Slovak language)

Probstl, U., Wirth, V., Elands, B., Bell, S. (Ed.) 2010. Management of Recreation and Nature Based Tourism in European Forests. Springer, 336.

Supuka, J., Vreštiak, P. 1984. Základy tvorby parkových lesov. Bratislava: VEDA, 226. (in Slovak language)

Štepánková, R., Bihuňová, M., Kabai, R. 2012. Design Principles of Public and Recreational Areas in the Urban Environment. Nitra: Slovak University of Agriculture in Nitra, 93.

Tai, L., Haque M.T., McLellan G.K.,Knight E.J. 20o6. Outdoor Environments for Children. Landscaping Schoolyards, Gardens and Playgrounds. New York: IBT Global, 380.

Tóth, A., Bihuňová, M., Halajová, D., Štepánková, R. 2014. Towards an inclusive approach to recreation and landscape protection. In: Public recreation and landscape protection - with man hand in hand. Brno: MENDELU, 335 - 339.

\section{|| || ||}

Internet 1: Ministry of the transport and regional development of the Slovak republic, 2013. Strategy for the tourism development by 2020, 46. (Slovak language), (12.12018).

Internet 2: The National Institute for Education http://www.statpedu.sk, (18.12.2017).

Internet 3: www.dropie.sazp.sk (15.1.2018). 